\title{
Rancang Bangun Sistem Informasi Pengelolaan Surat dan Kearsipan pada Sekretariat Daerah Provinsi NTB Berbasis Web
}

\author{
(The Design of Web Based Management Information System for Mail and Archives of \\ The Regional Secretariat of NTB Province)
}

\author{
Sumiati, Sri Endang Anjarwani, Moh. Ali Albar \\ Program Studi Teknik Informatika, Fakultas Teknik, Universitas Mataram. \\ Jl. Majapahit 62, Mataram, Lombok NTB, INDONESIA \\ Email: sumiati2694@gmail.com, endang@unram.ac.id, mohalialbar@unram.ac.id
}

\begin{abstract}
The development in Information System of Mail and Archives Management at the Governor Office of West Nusa Tenggara is still supported by manual process off disposition, archiving, search, and mail recapitulation report process. The aim at developing this system is to help the managing and archiving mail so staff in subsection Expedition and Archives can manage mailing and archiving quickly and precisely. This system is developed based on the programming language of HTML and PHP using framework CodeIgniter. It is examined through the Black box technique. The result is that every menu provided functions perfectly. The workflow of the information system has been suitable with the workflow of every work unit in the governor office of West Nusa Tenggara.
\end{abstract}

Key words: Information system, Mail and Archives Management, Framework CodeIgniter, Mean Opinion Score.

\section{PENDAHULUAN}

Pada era globalisasi seperti saat ini, kecepatan pengolahan dan penyampaian informasi memiliki peran yang sangat penting bagi setiap instansi, terutama instansi yang memiliki tingkat rutinitas yang tinggi dan memiliki banyak data yang harus diolah.

Pada Sekretariat Daerah Provinsi NTB khususnya pada sub bagian ekspedisi dan arsip yang menangani proses pengelolaan dan pencatatan data-data surat masuk dan surat keluar masih menggunakan prosedur-prosedur kerja manual yaitu menggunakan buku besar dan excel yang akan dikhwatirkan terjadinya kerusakan atau hilang, tulisan sulit dibaca oleh pegawai-pegawai lain dan kadang terjadi kekeliruan atau kesalahan pada lembar disposisi sehingga sulit untuk mencerna maksud dari isi disposisi dan akibatnya penginputan kolom disposisi surat menjadi terhambat.

Proses pengelohan data surat menggunakan microsof excel masih memiliki kendala yaitu keamanan data yang kurang terjamin, proses disposisi surat memerlukan banyak waktu dan tenaga karena jarak ruangan antara penerima surat dengan ruangan Ekpedisi dan Arsip yang cukup jauh, selain itu pada proses disposisi surat di Sekretariat Daerah Provinsi NTB pengirim surat akan mencari sendiri disposisi keberadaan surat yang dikirm. Pada proses penyimpanan arsip surat masuk dan surat keluar yang masih menggunakan berkasberkas yang kemudian disimpan kedalam map besar dan disusun didalam rak-rak buku akan menyebabkan kurangnya keamanan data sehingga dapat terjadi kehilangan data ketika sewaktu-waktu data surat diperlukan dan rusak termakan usia, selain itu pada proses pencarian surat membutuhkan waktu yang lama karena harus membongkar arsip surat untuk dapat menemukan surat yang diperlukan. Proses pembuatan laporan surat masuk dan surat keluar masih merasa kesulitan hal ini disebabkan karena harus membuka kembali buku agenda yang ada sehingga pekerjaan menjadi kurang efektif. Maslah-masalah yang terjadi khusunya pada sub bagian Ekspedisi dan Arsip disebabkan oleh tidak adanya sistem yang mampu mengelolah dan menyimpan surat dalam jumlah yang besar secara cepat.

Berdasarkan kekurangan-kekurangan yang ada pada Sekretariat Daerah Provinsi NTB mengharuskan pegawai terus melakukan perubahan dan terobosan menyesuaikan dengan kemajuan teknologi untuk memenuhi tugas-tugas yang ada, agar dapat memberikan pelayanan yang lebih memadai bagi masyarakat. Oleh karena itu sistem informasi pengolahan surat dan kearsipan dibangun untuk dapat mempermudah dalam proses pengelohan data surat masuk dan surat keluar, proses disposisi surat masuk, proses pengarsipan surat masuk dan surat keluar, proses pencarian data surat masuk dan surat keluar, proses rekapitulasi surat masuk an surat keluar bulanan serta menjadi solusi yang tepat untuk menyimpan data dalam jumlah yang besar dengan cepat serta informasiinformasi yang dihasilkan lebih akurat.

\section{TinjauAn PUSTAKA}

Sistem informasi pengelolaan surat dan kearsipan telah banyak dibangun dan diimplementasikan. Salah satu penelitian yang telah mengimplementasikan sistem informasi pengelolaan surat dan kearsipan yang dilakukan 
oleh Hidayat pada Kantor Kepala Desa Tridadi Kecamatan Sleman Kabupaten Sleman Berbasis Visual Basic. Sistem Informasi Kearsipan Surat Keluar dan Surat Masuk berbasis visual basic ini dapat mempermudah pencarian data pencatatan surat masuk dan surat keluar, serta pengklasifikasiannya sehingga memudahkan dalam temu balik arsip, serta nantinya dapat membantu dalam pembuatan laporan terhadap atasan [1].

Penelitian lainnya yang telah mengimplementasikan sistem informasi pengelolaan surat dan kearsipan yang dilakukan oleh Junidar pada Universitas U'Budiyah Indonesia Menggunakan Php dan MySql. Sistem informasi arsip surat menyurat ini, memudahkan mahasiswa dalam melakukan proses permintaan pembuatan surat melalui aplikasi kepada pihak akademik tanpa harus mendatangi pihak akademik langsung [2].

Selain itu sistem informasi pengelolaan surat dan kearsipan yang dilakukan oleh Permana pada Kecamatan Ketapang Kabupaten Bandung. Sistem informasi administrasi surat masuk dan surat keluar telah diimplementasikan dengan hasil memudahkan dalam pencarian surat masuk dan surat keluar serta dokumentasi yang lebih tertata rapi [3].

Penelitian mengenai sistem informasi surat yang serupa dilakukan oleh Setyawan pada Universitas Islam Negeri Sunan Kalijaga Menggunakan Pendekatan Agile Process dengan Model Extreme Programming. Sistem informasi surat menyurat dapat memudahkan pegawai Tata Usaha dalam membuat laporan bulanan dan tahunan serta memudahkan dalam pembuatan surat [4].

Penelitian mengenai sistem informasi surat yang serupa pernah dilakukan oleh Sumiati pada Praktek Kerja Lapangan (PKL) di Sub Bagian Ekspedisi dan Arsip Biro Umum Sekretariat Daerah Provinsi NTB. Sistem informasi pengolahan surat dan kearsipan pada PKL hanya sebatas pada analisa perancangan yang menghasilkan sebuah analisa sistem proses surat menyurat pada Sub Bagian Ekspedisi dan Arsip Biro Umum Sekretariat Daerah Provinsi NTB [5].

\section{Metode PENELITIAN}

Diagram alir dari sistem informasi pengelolaan surat dan kearsipan pada Sekretariat Daerah Provinsi Nusa Tenggara Barat dapat dilihat pada Gambar 1.

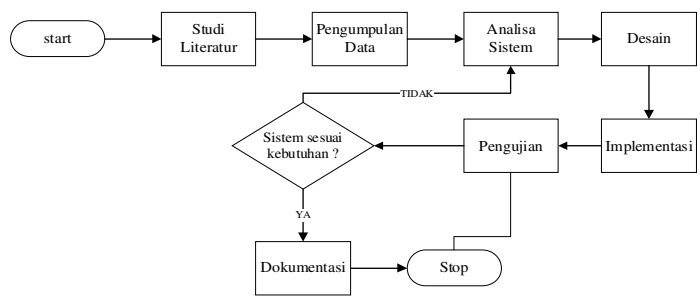

Gambar 1. Diagram alir sistem informasi pengelolaan surat dan kearsipan

\section{A. Studi Literatur}

Studi literatur mempelajari hal-hal yang terkait dengan pengembangan sistem. Perancangan sistem informasi pengelolaan surat dan kearsipan menggunakan metode waterfall, framework Codeigniter dan twitter bootstrap dalam membangun sistem.

\section{B. Pengumpulan Data}

Pengumpulan data dilakukan studi kasus pada kantor Gubernur Provinsi Nusa Tenggara Barat dengan berapa metode diantaranya :

\section{- Metode wawancara}

Wawancara dilakukan kepada staff bagian kearsipan untuk mendapatkan informasi mengenai sistem pengelolaan surat dan arsip yang sedang berjalan dan informasi mengenai sistem yang diharapkan.

- Metode observasi

Observasi atau melakukan peninjauan secara langsung pada Sub Bagian Ekspedisi dan Arsip untuk mengetahui proses sistem yang sedang berjalan.

\section{Analisa Sistem}

Analisa kebutuhan sistem yang digunakan untuk membangun sistem informasi pengelolaan surat dan kearsipan yaitu:

- Data surat masuk terdiri dari : tanggal terima, pengirim, penerima, tanggal surat, nomor surat, perihal, klasifikasi surat dan scan surat.

- Data surat keluar terdiri dari : tanggal kirim, penerima, pengirim, tanggal surat, nomor surat, perihal, klasifikasi surat, dan scan surat.

- Data arsip surat masuk terdiri dari : tanggal terima, pengirim, penerima, tanggal surat, nomor surat, perihal, klasifikasi surat, scan surat, nomor bok, nomor rak, dan nomor fisis.

- Data arsip surat keluar teridiri dari : tanggal terima, pengirim, penerima, tanggal surat, nomor surat, perihal, klasifikasi surat, scan surat, nomor bok, nomor rak, dan nomor fisis.

- Data bagian atau biro terdiri dari : kode bagian dan nama bagian.

- Data klasifikasi surat yang terdiri dari : kode klasifikasi dan nama klasifikasi.

- Data pegawai bagian atau biro yang terdiri dari : nip, nama, alamat, bagian, jenis kelamin, TMT (Terhitung Mulai Tanggal) golongan terakhir, golongan, jabatan, agama, pendidikan terakhir.

- Proses pada sistem informasi pengelolaan surat dan kearsipan yaitu mengelola surat masuk dan keluar, mengarsipkan surat masuk dan keluar, monitoring disposisi surat masuk.

- Informasi yang dihasilkan sistem informasi pengelolaan surat dan kearsipan yaitu mengetahui status disposisi dan keberadaan surat masuk, membuat laporan surat masuk dan keluar bulanan

\section{Desain Sistem}

Tahap design merupakan tahap penggambaran suatu sistem yang akan dikembangkan 


\section{D.1. User case diagram}

Use case diagram sistem informasi pengelolaan surat dan kearsipan digunakan untuk menjelaskan kegiatan dari aktor yang dapat dilakukan oleh petugas Ekspedisi dan Arsip dan pegawai Biro Gubernuran pada sistem.

Perancangan use case diagram sistem pengelolaan surat dan kearsipan dapat dilihat pada Gambar 2.

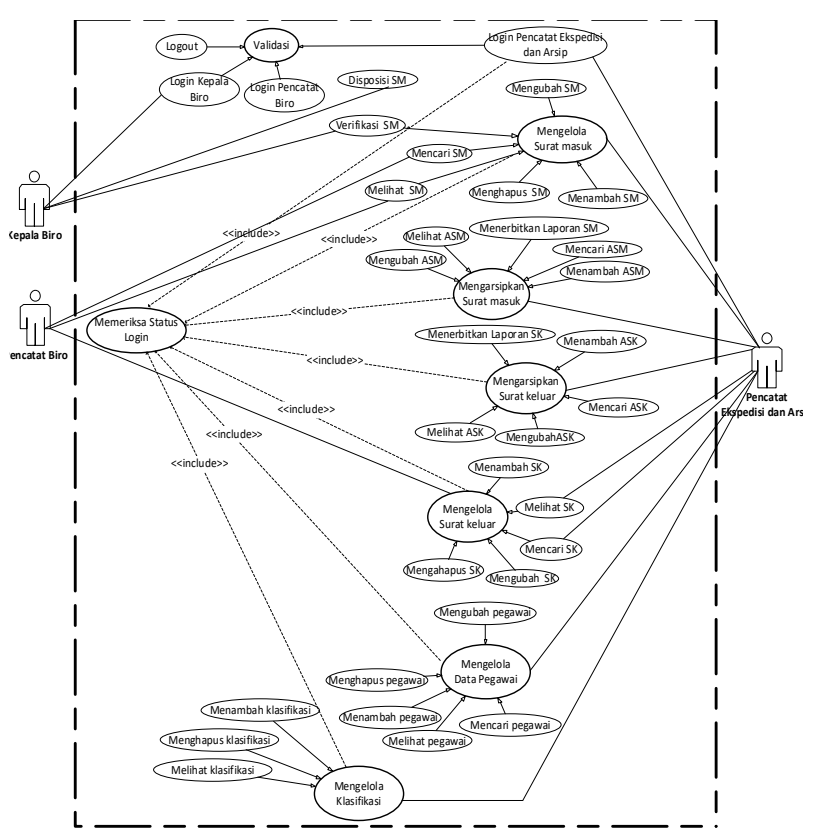

Gambar 2. Use case diagram sistem pengelolaan surat dan kearsipan

\section{D.2. Entity relationship diagram (ERD)}

ERD merupakan model yang menjelaskan hubungan antar data dalam database berdasarkan objek-objek dasar data. Perancangan ERD sistem pengelolaan surat dan kearsipan dapat dilihat pada Gambar 3.

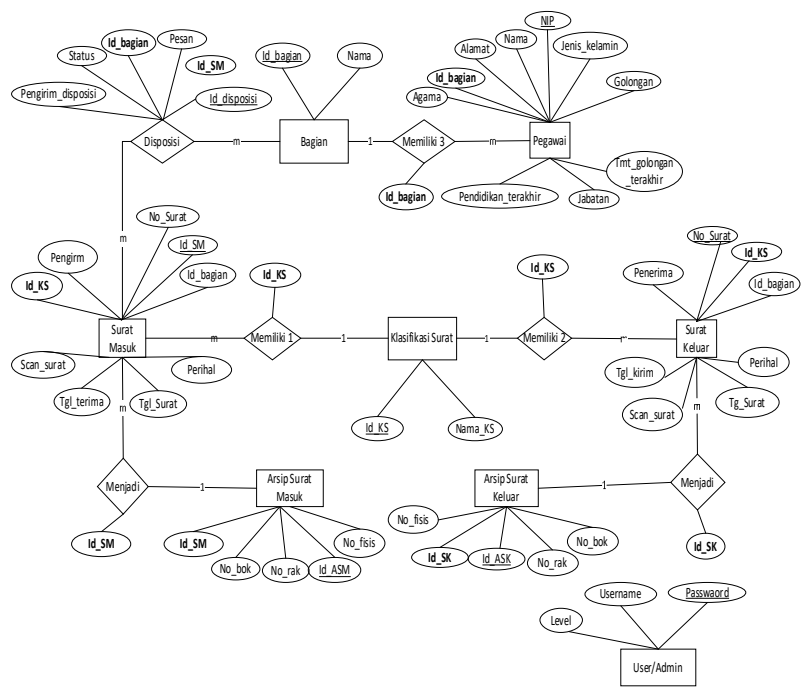

Gambar 3. ERD sistem pengelolaan surat dan kearsipan

\section{D.3. Class diagram}

Class diagram merupakan diagram yang menunjukkan class-class yang ada di sistem dan hubungannya secara logic. Class diagram pada sistem informasi pengelolaan surat dan kearsipan dapat dilihat pada Gambar 4.

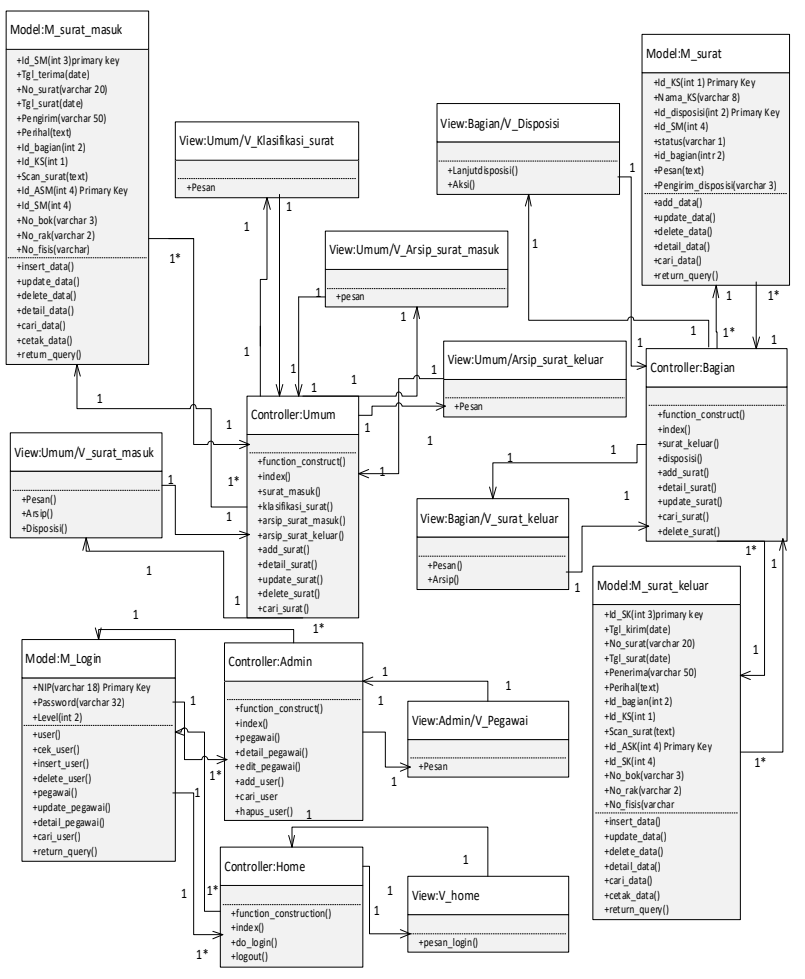

Gambar 4. Class diagram sistem pengelolaan surat dan kearsipan

\section{D.4. Sequence diagram}

Sequence diagram menggambarkan interaksi antar objek di dalam dan di sekitar sistem (termasuk pengguna dan display) berupa message yang digambarkan terhadap waktu.

1. Sequence Diagram Login Sistem Informasi Pengelolaan Surat dan Kearsipan dapat dilihat pada Gambar 5.

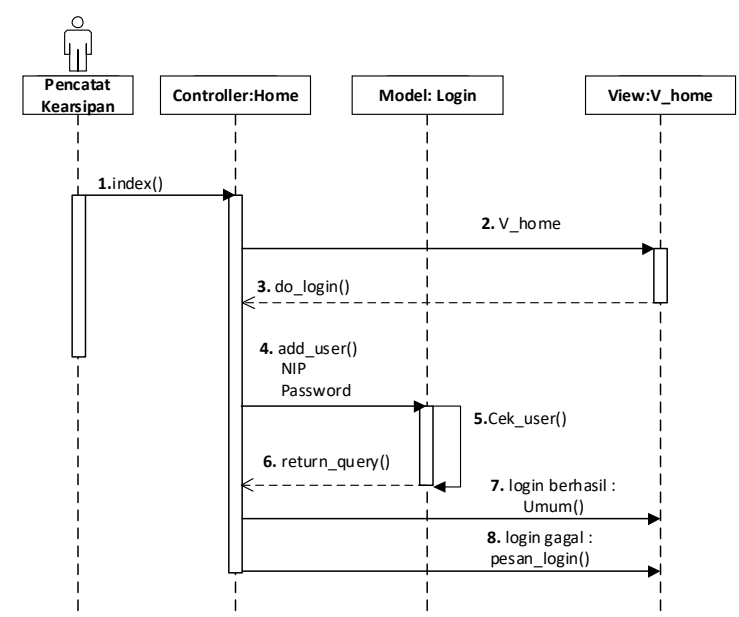

Gambar 5. Sequence diagram login admin (Pencatat Kearsipan)

Hal pertama yang dilakukan adalah sistem akan mengakses fungsi index()kemudian sistem akan 
menampilkan halaman login dengan mengakses link V_home dan method atau fungsi do_login() pada controller home. admin menginputkan data login yaitu username dan password, data login yang ada pada database akan dicek kembali dengan fungsi cek_user(). Jika data login yang diinputkan benar maka proses login berhasil dan jika data login yang diinputkan salah maka admin akan diarahkan pada halaman login dan menampilkan pesan

2. Sequence diagram kelola surat masuk dapat dilihat pada Gambar 6.

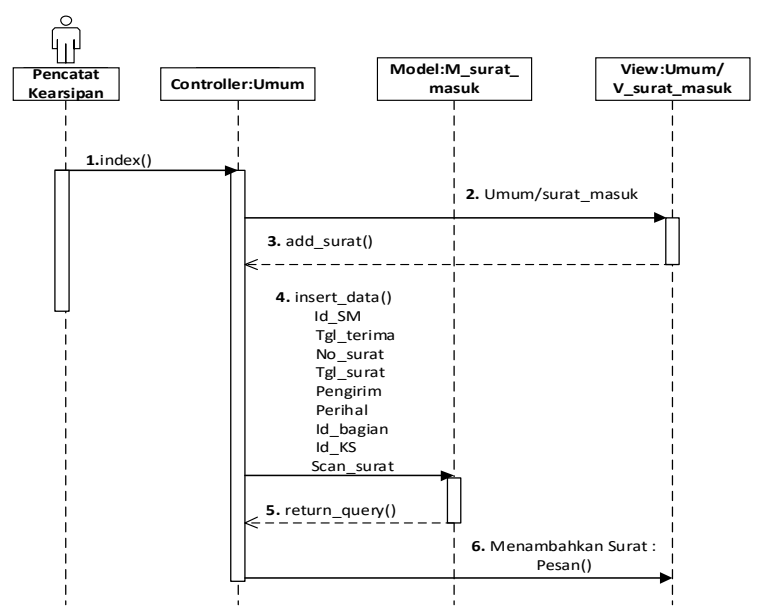

Gambar 6. Sequece diagram menambah surat masuk

Hal pertama yang dilakukan adalah sistem akan mengakses fungsi index() kemudian sistem akan menampilkan halaman surat masuk dengan mengakses link Umum/surat_masuk dan method atau fungsi add_surat() pada controller Umum. admin menginputkan data surat masuk yaitu id_SM, Tgl_terima, No_surat, Tgl_surat, Pengirim, Perihal, Id_bagian, Id_KS, dan Scan_surat. Jika data surat masuk yang diinputkan benar maka akan menampilkan pesan.

3. Sequence diagram disposisi surat masuk dapat dilihat pada Gbr 7.

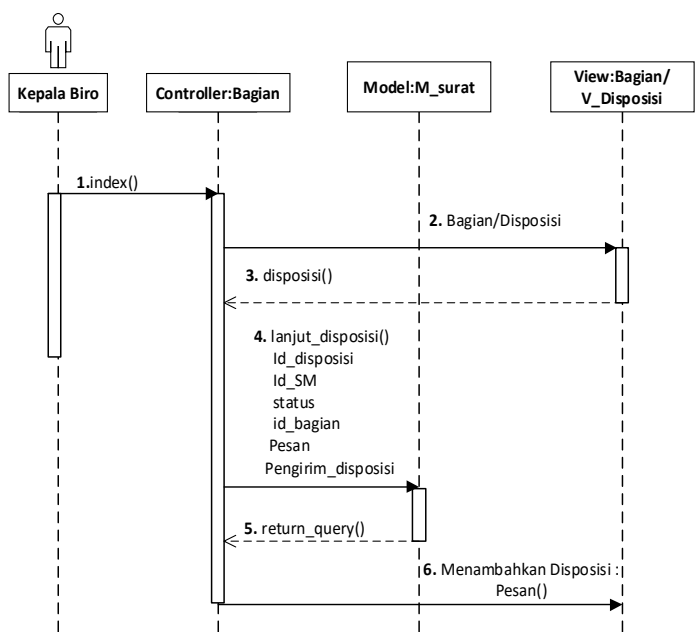

Gambar 7. Sequence diagram disposisi surat masuk
Hal pertama yang dilakukan adalah sistem akan mengakses fungsi index() kemudian sistem akan menampilkan halaman surat masuk dengan mengakses link Bagian/Disposisi dan method atau fungsi disposisi() pada controller Bagian. Kepala biro mendisposisi surat masuk dengn menginputkan yaitu id_disposisi, Id_SM, status, Id_bagian, pesan dan pengirim_disposisi. Jika data disposisi yang dinputkan benar dan telah trdisposisi maka sistem akan menampilkan pesan.

4. Sequence diagram kelola arsip surat masuk dapat dilihat pada Gambar 8.

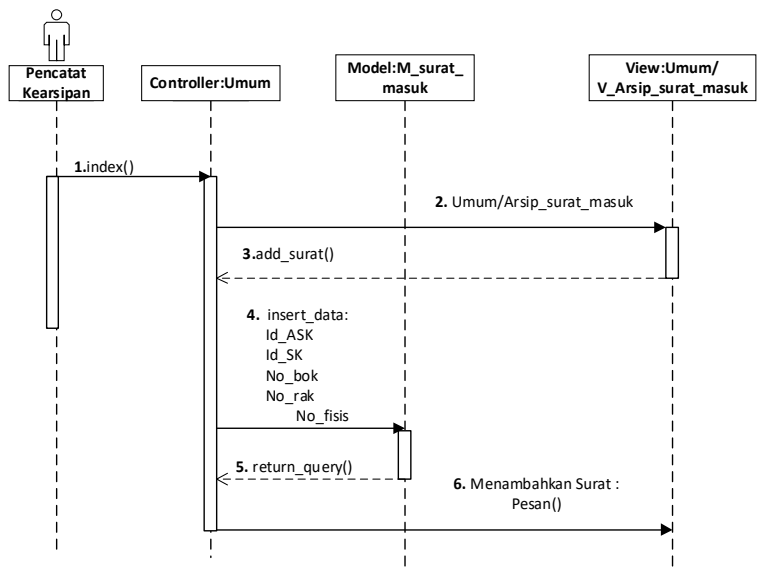

Gambar 8. Sequece diagram menambah arsip surat masuk

Hal pertama yang dilakukan adalah sistem akan mengakses fungsi index() kemudian sistem akan menampilkan halaman surat masuk dengan mengakses link Umum/V_Arsip_surat_masuk dan method atau fungsi add_surat() pada controller Umum. Admin menginputkan data arsip surat masuk yaitu id_ASM, Id_SM, No_bok, No_rak, dan No_fisis. Jika data arsip surat masuk yang diinputkan benar maka proses menambahkan arsip surat berhasil dan menampilkan pesan.

5. Sequence diagram menerbitkan laporan surat masuk dapat dilihat pada Gambar 9.

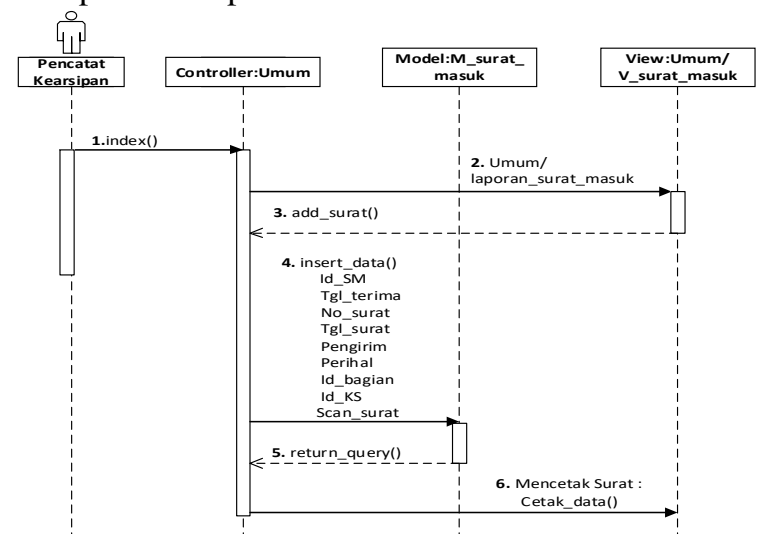

Gambar 9 Sequence diagram menerbitkan laporan surat masuk 
Hal pertama yang dilakukan adalah sistem akan mengakses fungsi index() kemudian sistem akan menampilkan halaman laporan surat masuk dengan mengakses link Umum/laporan_surat_masuk dan method atau fungsi add_surat () pada controller Umum. Admin mencetak data surat masuk ada didalam database yaitu id_SM, Tgl_terima, No_surat, Tgl_surat, Pengirim, Perihal, Id_bagian, Id_KS, dan Scan_surat. Jika data laporan surat masuk yang akan dicetak telah tersedia maka admin dapat melakukan proses cetak laporan surat masuk.

\section{D.5. Activity diagram}

Activity diagram menggambarkan alur kerja sebuah urutan aktivitas pada suatu proses. Activity diagram sistem informasi pengelolaan surat dan kearsipan dapat dilihat pada Gambar 10.

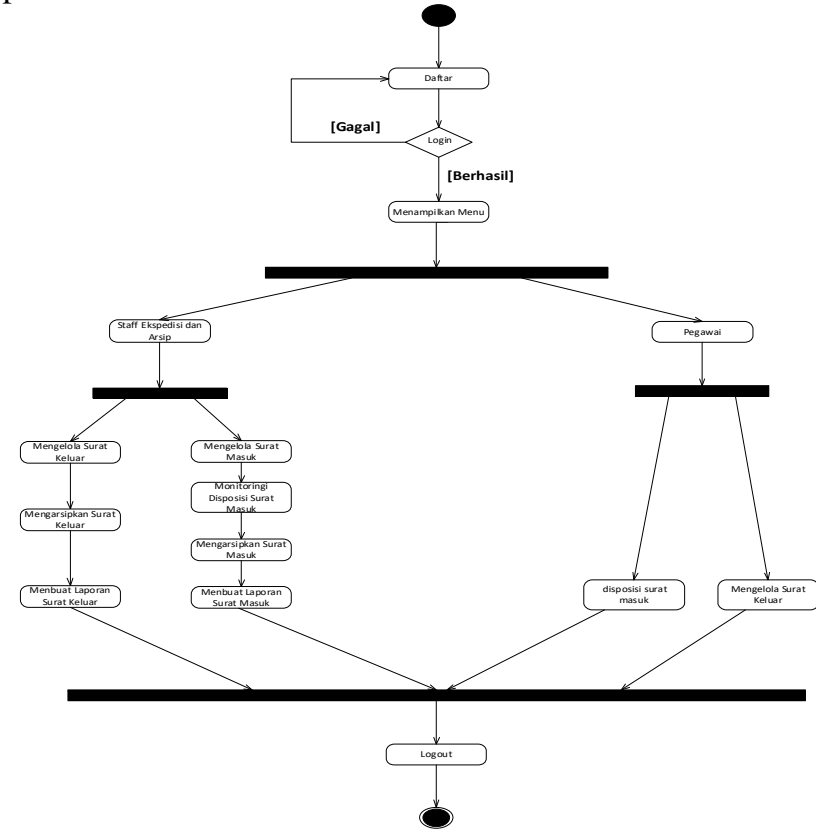

Gambar 10. Activity Diagram Sistem Informasi Pengelolaan Surat dan Kearsipan

\section{D.6. Design interface}

Perancangan antarmuka dibuat sebagai gambaran mengenai user interface yang akan dibangun.

1. Desain Interface Administrator (Staff Ekspedisi dan Arsip)

Pada halaman login user diminta untuk memasukkan username dan password untuk dapat masuk kedalam sistem, setelah user berhasil login maka sistem akan mengarahkan pada Interface Home Administrator dapat dilihat pada Gambar 11.

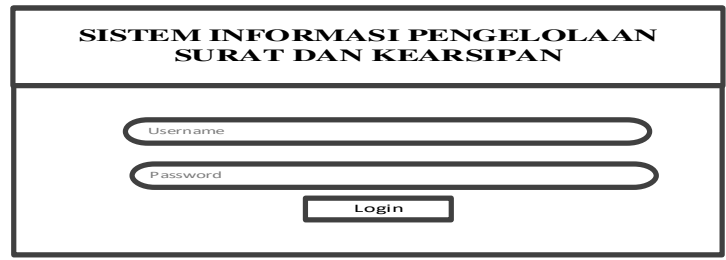

Gambar 11 Desain Form Login Administrator
2. Desain Interface Home Administrator (Staff Ekspedisi dan Arsip)

Pada tampilan home administrator sistem infromasi pengelolaan surat dan kearsipan terdiri dari menu-menu yaitu menu surat, arsip surat, laporan, klasifikasi, disposisi surat selain itu terdapat logout yang berfungsi untuk keluar dari sistem dapat dilihat pada Gambar 12.

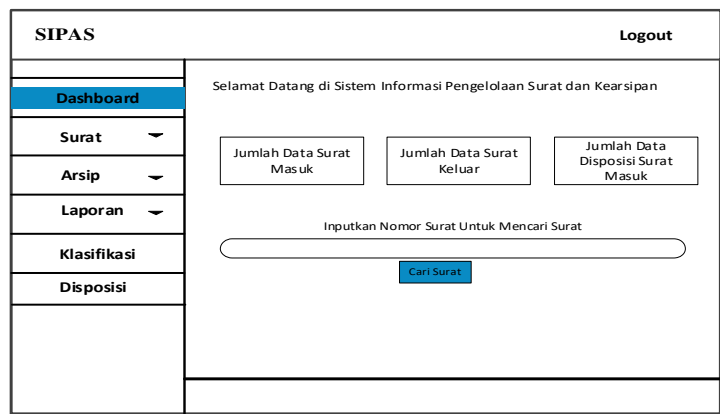

Gambar 12. Desain Tampilan Home Administrator (Staff Ekspedisi dan Arsip)

\section{Desain Tampilan Menu Surat}

Pada saat admin memilih menu surat masuk maka sistem akan menampilkan data surat masuk, pada tabel surat masuk terdapat beberapa proses yaitu proses cari surat, tambah data, detail, disposisi, arsip dan hapus surat masuk dapat dilihat pada Gambar 13.

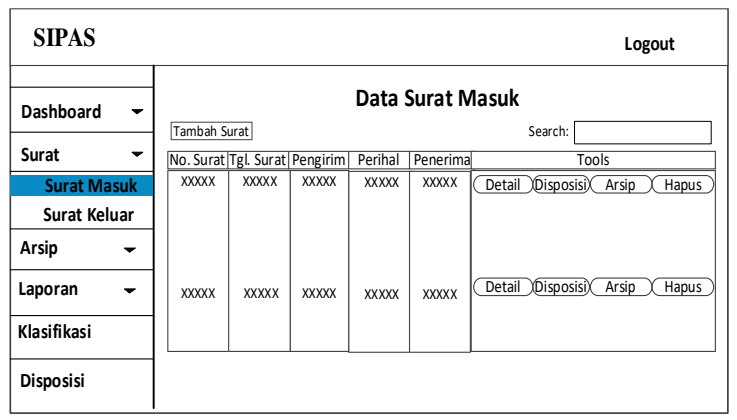

Gambar 13. Desain tampilan menu data surat masuk

Pada saat staff Ekspedisi dan Arsip memilih proses tambah surat maka akan menampilkan form untuk menginputkan data-data surat masuk yaitu nomor surat, tanggal surat, pengirim, perihal, penerima, klasifikasi, dan foto surat dapat dilihat pada Gambar 14.

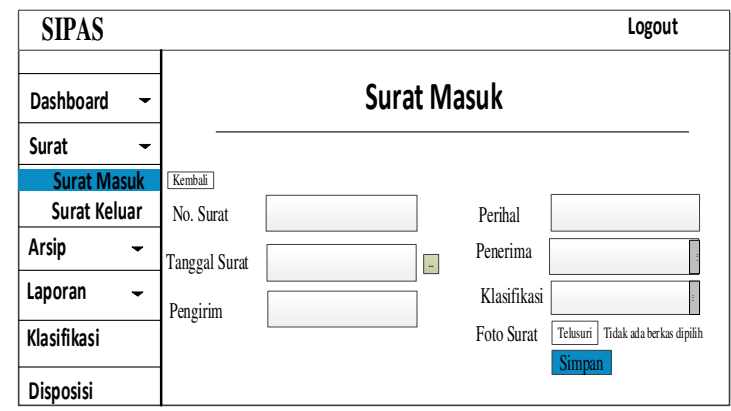

Gambar 14 Desain tampilan form surat masuk 
Pada saat staff Ekspedisi dan Arsip memilih proses disposisi maka staff Ekspedisi dan Arsip menginputkan penerima disposisi berikutnya dan pesan disposisi dapat dilihat pada Gambar 15.

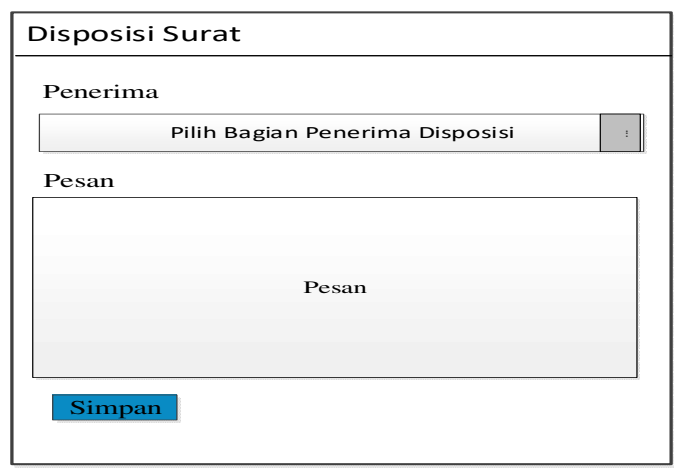

Gambar 15. Desain tampilan proses disposisi data surat masuk

Pada saat staff Ekspedisi dan Arsip memilih proses arsip surat maka akan menampilkan form untuk menginputkan data arsip surat masuk yaitu nomor bok, nomor rak, dan nomor fisis surat dapat dilihat pada Gambar 16.

\begin{tabular}{|c|}
\hline Arsip Surat Masuk \\
\hline No. Surat \\
\hline$x x x x x$ \\
\hline No. Bok \\
\hline$x x x x x$ \\
\hline No. Rak \\
\hline$x x x x x$ \\
\hline No. Fisis \\
\hline$x x x x x$ \\
\hline
\end{tabular}

Gambar 16. Desain tampilan form arsip surat masuk

\section{Desain Tampilan Menu Laporan Surat}

Pada saat staff Ekspedisi dan Arsip memilih menu laporan surat masuk maka akan sistem akan menampilkan data laporan surat masuk. Pada tabel laporan surat masuk terdapat proses cari surat, filter dan cetak laporan. dapat dilihat pada Gambar 17.

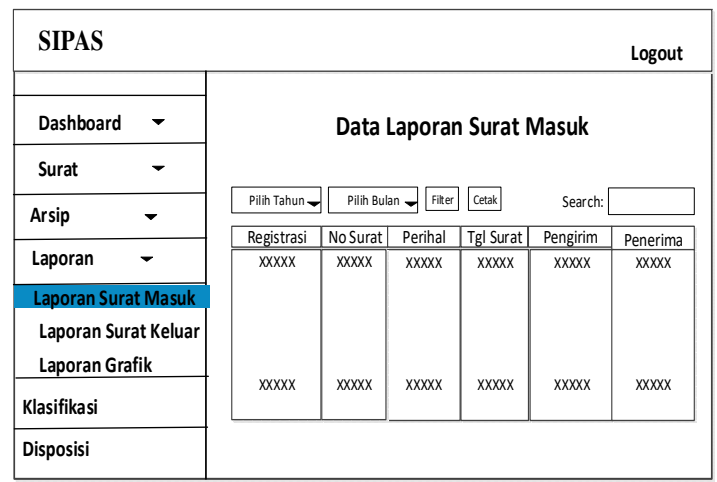

Gambar 17 Desain tampilan laporan surat masuk
Pada saat staff Ekspedisi dan Arsip memilih proses cetak maka akan terlihat laporan dari surat masuk dapat dilihat pada Gambar 18.

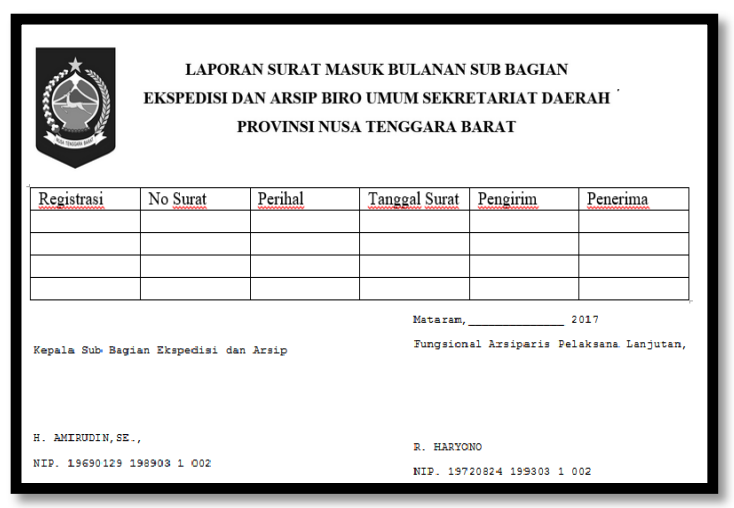

Gambar 18. Desain tampilan laporan surat keluar

Pada saat staff Ekspedisi dan Arsip memilih laporan grafik maka sistem akan menampilkan data laporan surat masuk dan surat keluar bulanan dalam bentuk grafik dapat dilihat pada Gambar 19.

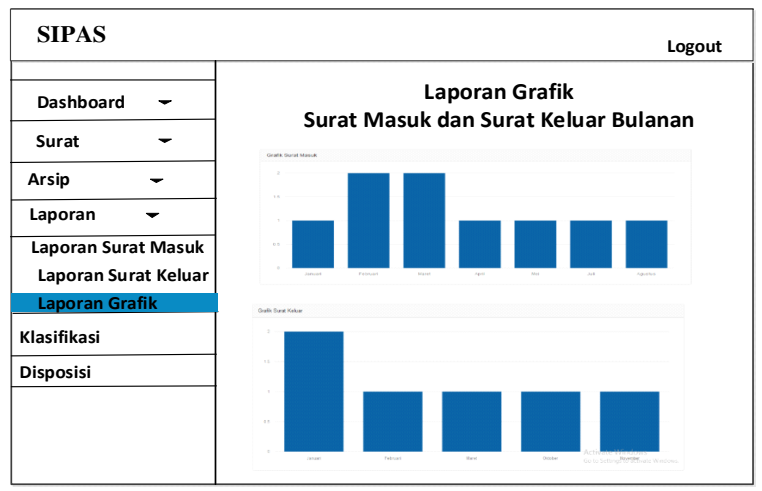

Gambar 19. Desain tampilan laporan grafik surat

\section{HASIL DAN PEMBAHASAN}

Pada bagian ini, akan menjelaskan mengenai implementasi rancangan sistem, implementasi database sistem dan implementasi interface sistem. Selain itu, juga akan membahas mengenai hasil dari sistem yang telah dibuat dan pengujian terhadap sistem

\section{A. Implementasi Sistem}

Perancangan class dibangun berdasarkan struktur pada framework CodeIgniter yang terdiri dari MVC (Model, View, Controller). Implementasi class pada models dapat dilihat pada Gambar 20.

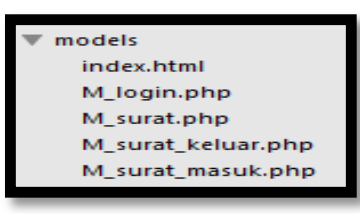

Gambar 20. implementasi class pada model 
Implementasi class pada controller dapat dilihat pada Gambar 21.

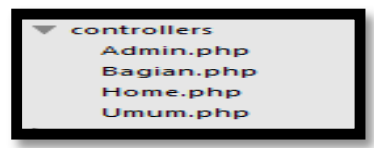

Gambar 21. implementasi class pada controller

Implementasi class pada view dapat dilihat pada Gambar 22.

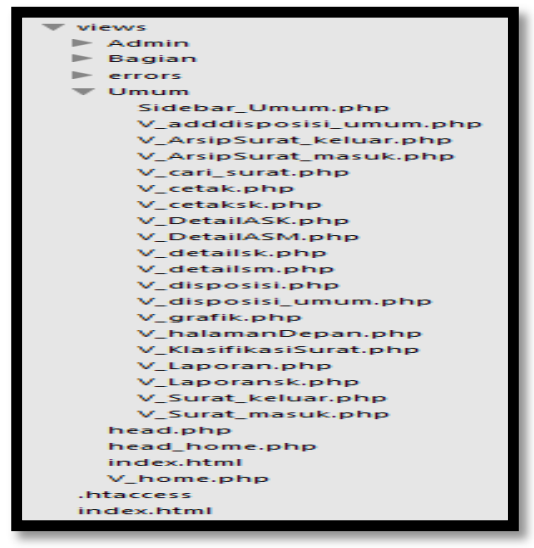

Gambar 22. implementasi class pada view

\section{B. Implementasi Database}

Database yang digunakan untuk membangun sistem informasi pengelolaan surat dan kearsipan yaitu database surat terdiri dari beberapa tabel tabel_admin, tabel_arsip_surat_keluar, tabel_arsip_surat_masuk, tabel_bagian, tabel_disposisi, tabel_klasifikasi_surat, tabel_pegawai, tabel_surat_keluar, dan tabel_surat_masuk seperti yang terlihat pada Gambar 23.

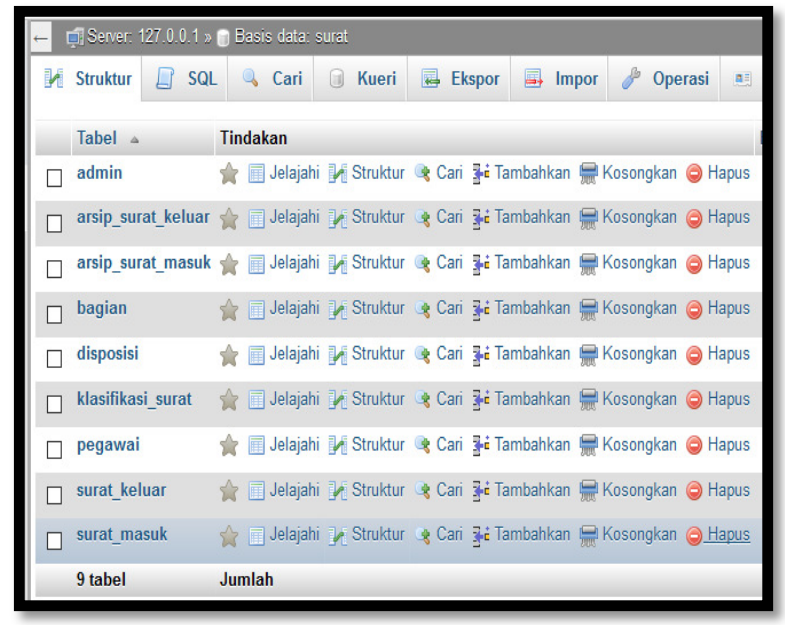

Gambar 23. implementasi database

\section{Implementasi Interface Sistem}

Interface sistem merupakan antar muka yang berinteraksi secara langsung dengan pengguna.
1. Interface Form Login Administrator (Staff Ekspedisi dan Arsip)

Pada halaman login user diminta untuk memasukkan data-data berupa NIP sebagai username dan password untuk dapat masuk kedalam sistem, setelah user berhasil login maka sistem akan mengarahkan pada Interface Home Administrator dapat dilihat pada Gambar 24.

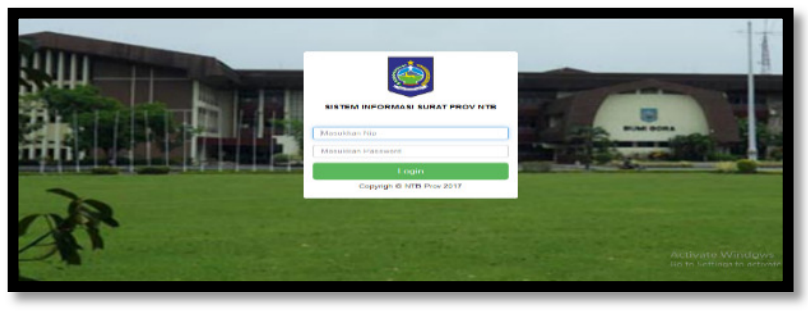

Gambar 24 Interface Form Login Administrator

2. Interface Home Administrator (Staff Ekspedisi dan Arsip)

Setelah user berhasil login ke dalam sistem maka akan terlihat tampilan halaman home administrator yang terdapat menu-menu yang terdiri dari menu surat, menu arsip surat, laporan surat, klasifikasi surat, dan disposisi surat dapat dilihat pada Gambar 25.

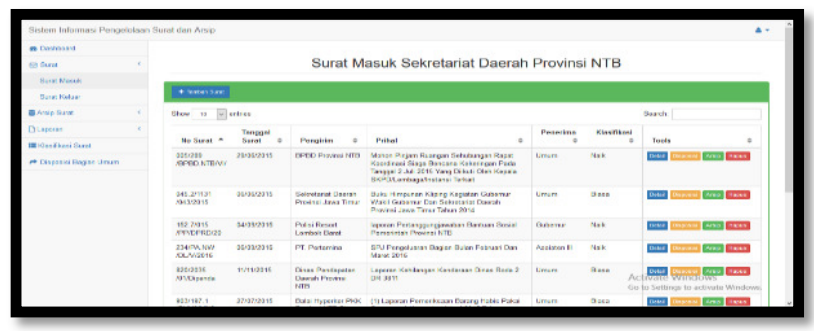

Gambar 25. Tampilan Home Administrator

3. Tampilan Menu Surat Masuk

Pada saat admin memilih menu surat masuk maka sistem akan menampilkan data surat masuk, Pada halaman ini, admin dapat melakukan beberapa proses yaitu proses cari surat, tambah data, detail, disposisi, arsip dan hapus surat masuk dapat dilihat pada Gambar 26.

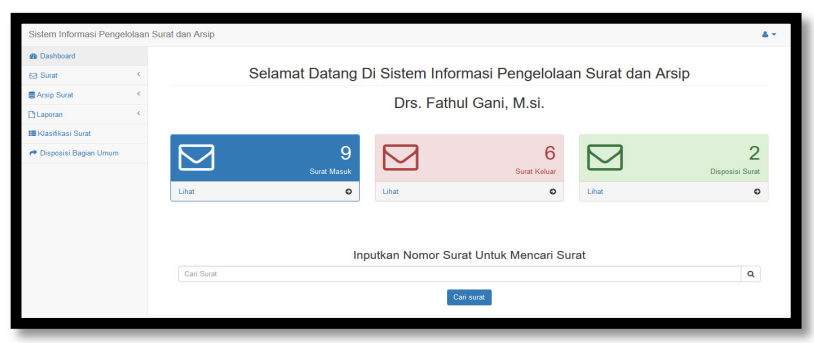

Gambar 26. Tampilan menu data surat masuk 


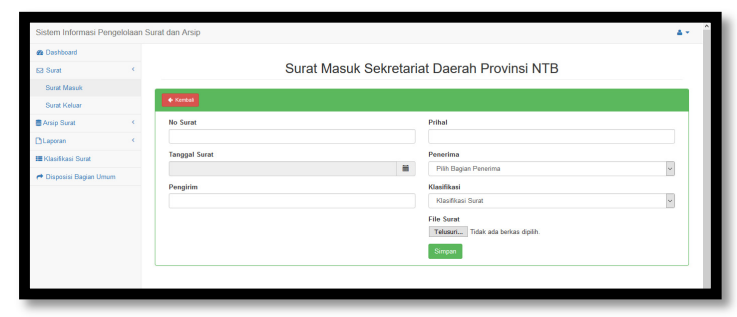

Gambar 27. Tampilan form surat masuk

Pada saat admin memilih proses tambah surat maka akan menampilkan form surat masuk dapat dilihat pada Gambar 27. Form surat masuk untuk menginputkan data-data surat masuk yaitu nomor surat, tanggal surat, pengirim, perihal, penerima, klasifikasi, dan foto surat. Pada saat pegawai memilih proses disposisi maka pegawai menginputkan penerima disposisi berikutnya dan pesan disposisi dapat dilihat pada Gambar 28.

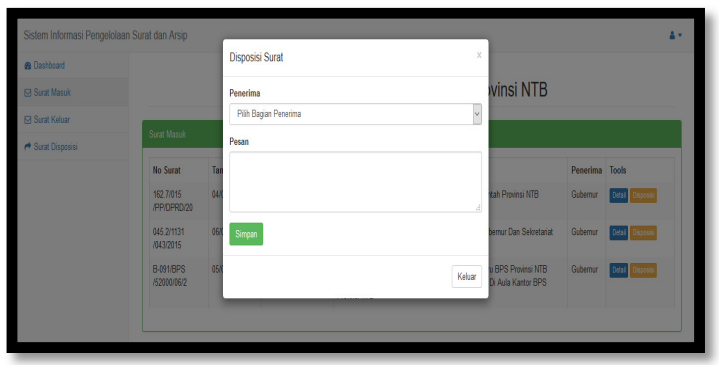

Gambar 28. Tampilan proses disposisi data surat masuk

Pada saat staff Ekspedisi dan Arsip memilih proses arsip surat maka akan menampilkan form untuk menginputkan data arsip surat keluar yaitu nomor bok, nomor rak, dan nomor fisis surat dapat dilihat pada Gambar 29.

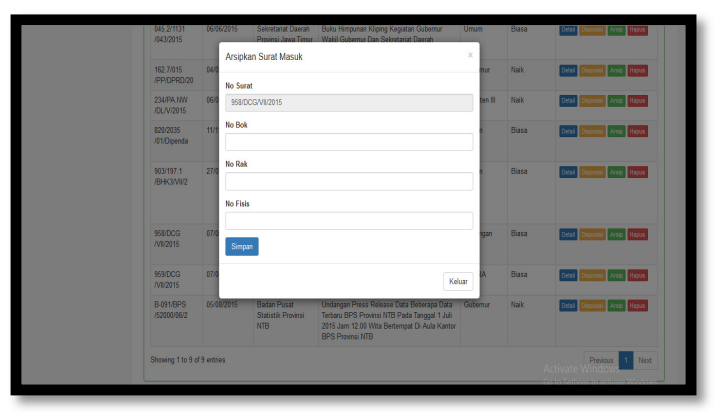

Gambar 29. Tampilan form arsip surat masuk

4. Tampilan menu laporan surat

Pada saat staff Ekspedisi dan Arsip memilih menu laporan surat masuk maka akan sistem akan menampilkan data laporan surat masuk. Pada tabel laporan surat masuk terdapat proses cari surat, filter dan cetak laporan dapat dilihat pada Gambar 30.

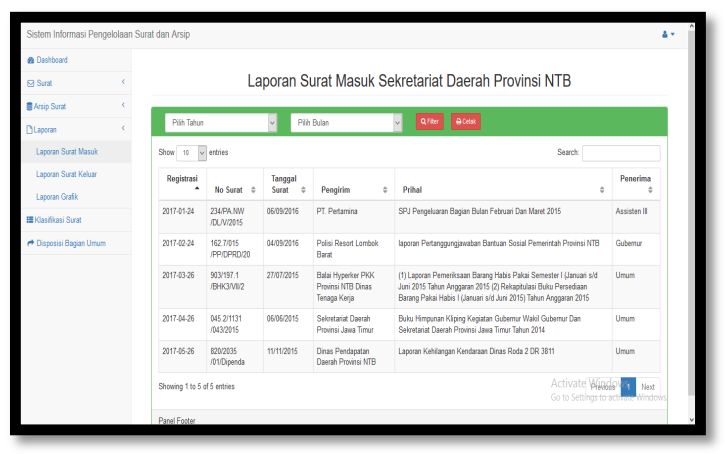

Gambar 30 Desain tampilan laporan surat masuk

Pada saat staff Ekspedisi dan Arsip memilih proses cetak maka akan terlihat laporan dari surat masuk dapat dilihat pada Gambar 31 .

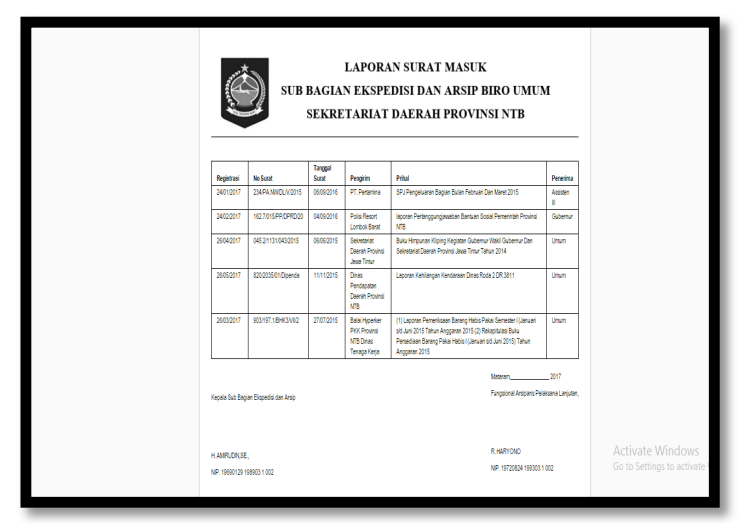

Gambar 31. Tampilan laporan surat masuk

Pada saat staff Ekspedisi dan Arsip memilih laporan grafik maka sistem akan menampilkan data laporan surat masuk dan surat keluar bulanan dalam bentuk grafik dapat dilihat pada Gambar 32.

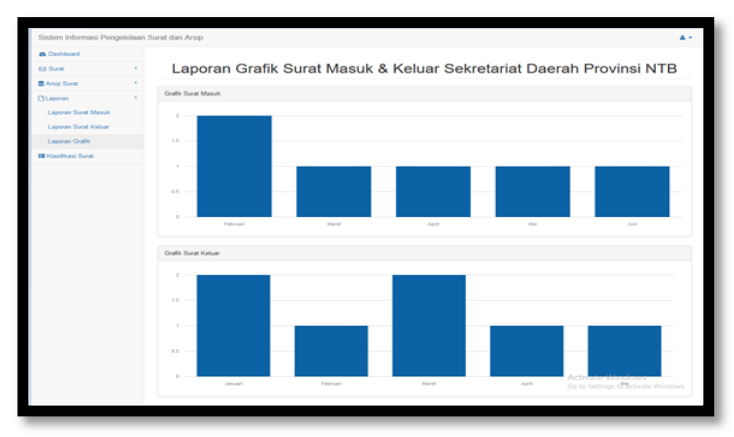

Gambar 32. Tampilan laporan grafik surat

\section{Pengujian Sistem}

Tahap pengujian sistem dilakukan untuk mengetahui sistem telah berjalan sesuai dengan sistem yang telah diusulkan.

\section{D.1.Hasil pengujian metode black box}

Metode pengujian black box merupakan metode pengujian yang menguji fungsi-fungsi didalam sistem 
untuk menentukan apakah fungsi-fungsi tersebut sudah berjalan sesuai harapan atau tidak.

Berdasarkan pengujian black box yang telah dilakukan terhadap seluruh fungsi yang ada didalam sistem, fungsifungsi yang ada pada sistem telah diuji dengan berbagai kondisi dan data masukan yang berbeda-beda, dengan hasil pengujian yang telah dilakukan maka dapat disimpulkan bahwa fungsi-fungsi yang telah ada pada sistem informasi pengelolaan surat dan kearsipan sudah berjalan dengan baik yaitu sistem informasi pengelolaan surat dan kearsipan dapat melakukan proses pengelolaan surat masuk dan surat keluar, proses pengarsipan surat masuk dan pengarsipan surat keluar, proses pendisposisian surat masuk, proses verifikasi surat masuk, proses rekapitulasi surat masuk dan surat keluar bulanan ataupun tahunan, serta proses tracking surat yang berfungsi serta proses tracking surat yang berfungsi untuk mempermudah admin dalam mencari disposisi surat yang dibutuhkan oleh pengirim surat.

\section{D.2. Hasil pengujian metode Mean Opinion Score}

Metode Mean Opinion Score (MOS) merupakan suatu penilaian kualitatif terhadap hasil citra.

Berdasaran hasil pengujian kuisioner yang dilakukan pada Staff Ekspedisi dan Arsip sebanyak 7 orang, maka dapat dihitung total keseluruhan dari pernyataan responden yaitu terdiri dari 33 jumlah pernyataan baik oleh responden dengan jumlah rata-rata persentase 94\%, dan 2 jumlah pernyataan tidak tahu dengan jumlah rata-rata persentase $6 \%$ dari 5 jumlah pertanyaan dan 7 pada kuisioner responden staff Ekspedisi dan Arsip. Adapun grafik jumlah persentase pernyataan rata-rata responden dari kuisioner yang telah diajukan dapat dilihat pada Gambar 33.

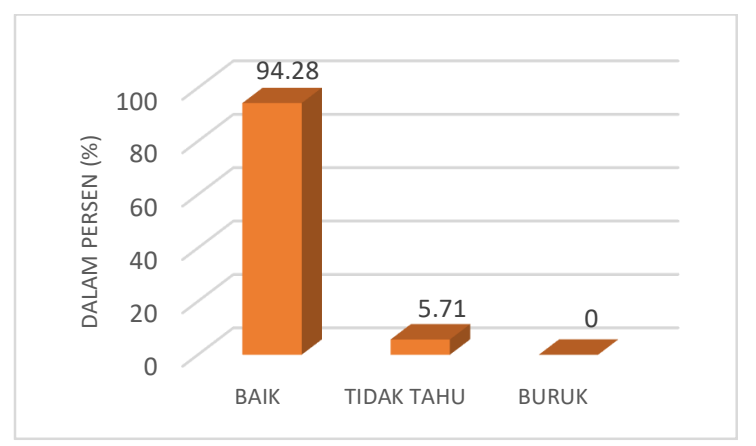

Gambar 33. Grafik persentase rata-rata pernyataan responden staff Ekspedisi dan Arsip

Berdasaran hasil pengujian kuisioner yang dilakukan pada mahasiswa sebnayk 23 orang, maka dapat dihitung total keseluruhan dari pernyataan responden yaitu terdiri dari 89 jumlah pernyataan baik oleh responden dengan jumlah rata-rata persentase $77 \%$, dan jumlah pernyataan tidak tahu dengan jumlah rata-rata persentase $23 \%$ dari 5 jumlah pertanyaan yang ada pada kuisioner Adapun grafik jumlah persentase pernyataan rata-rata responden dari kuisioner yang telah diajukan dapat dilihat pada Gambar 34.

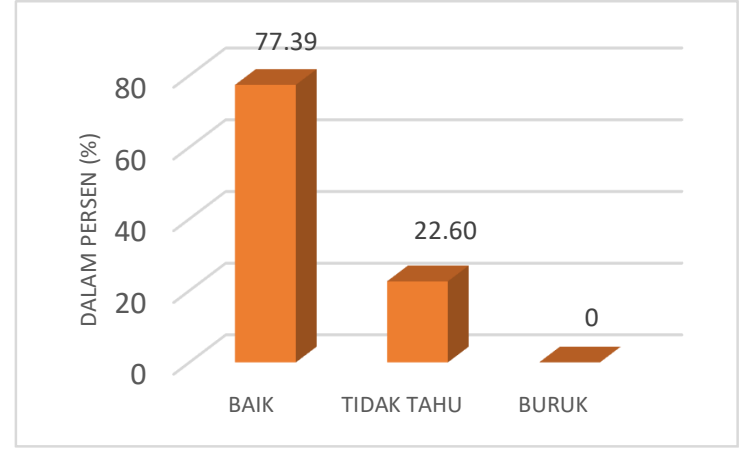

Gambar 34. Grafik persentase rata-rata pernyataan responden mahasiswa

\section{KESIMPULAN DAN SARAN}

\section{A. Kesimpulan}

Berdasarkan penelitian dan pembuatan sistem yang telah dilakukan, terdapat beberapa kesimpulan yaitu:

a. Pembuatan Sistem Informasi Pengelolaan Surat dan Kearsipan pada Kantor Gubernur Nusa Tenggara Barat dapat digunakan untuk mempermudah staff Ekspedisi dan Arsip dalam proses pengelolaan surat masuk dan surat keluar, pengarsipan surat masuk dan surat keluar, rekapitulasi laporan surat masuk dan surat keluar, monitoring disposisi surat masuk dan verifikasi status surat masuk.

b. Sistem informasi pengelolaan surat dan kearsipan terdapat proses tracking surat yang berfungsi untuk mempermudah admin dalam melakukan proses pencarian surat serta mengetahui keberadaan atau posisi surat yang dibutuhkan.

c. Hasil pengujian dengan metode black box seluruh fungsi telah sesuai dengan sistem yang diusulkan dan diharapkan oleh pengguna sistem khususnya pada sub bagian Ekspedisi dan Arsip.

d. Berdasarkan hasil pengujian metode Mean Opinion Score dapat disimpulkan bahwa sebesar 94\% responden staff Ekspedisi dan Arsip menyatakan mendukung dan sebesar $23 \%$ responden mahasiswa menyatakan tidak tahu dengan sistem informasi pengelolaan surat dan kearsipan.

\section{B. Saran}

Saran untuk pengembangan lebih lanjut pada sistem informasi pengelolaan surat dan kearsipan untuk pengembangan sistem lebih lanjut diantaranya:

a. Sistem Informasi Pengelolaan Surat dan Kearsipan pada Kantor Gubernur Nusa Tenggara Barat perlu dikembangkan atau diperluas scope dari sistem sehingga instansi diluar Sekretariat Daerah Provinsi NTB dapat menggunakan sistem informasi pengelolaan surat dan kearsipan.

b. Pada tools atau fitur disposisi diperlukan pengaman dalam proses disposisi dan penyampaian pesan rahasia atau penting ke bagian yang menerima disposisi surat

c. Pada fitur laporan surat masuk dan surat keluar bulanan dalam bentuk grafik, rekapitulasi surat tidak hanya perbulan atau pertahun tetapi diperlukan laporan 
berdasarkan penerima surat perbulannya, sehingga dapat diketahui jumlah surat yang masuk ke biro-biro perbulan atau pertahun.

\section{DAFTAR PUSTAKa}

[1] W. A. Hidayat, Sistem Kearsipan Surat Masuk dan Keluar di Kantor Kepala Desa Tridadi Kecamatan Sleman Kabupaten Sleman Berbasis Visual Basic. Yogyakarta:Jurusan informatika, Sekolah Tinggi Manajemen Informatika dan Komputer AMIKOM Yogyakarta, 2014.

[2] Junindar, Perancangan Sistem Informasi Arsip Surat Menyurat Di Universitas U'Budiyah Indonesia Menggunakan Php dan MySql. Jurusan teknik informatika, STMIK U'budiyah Indonesia, 2014.
[3] R. M. Permana, Perancangan Sistem Infromasi Administrasi Surat Masuk dan Surat Keluar Di Kecamatan Ketapang Kabupaten Bandung. Bandung: Jurusan Teknik Informatika, PKN LPKIA Bandung, 2014.

[4] D. F. Setyawan, Rancang Bangun Sistem Informasi Surat Universitas Islam Negeri Sunan Kalijaga Menggunakan Pendekatan Agile Process dengan Model Extreme Programming. Jogyakarta: Jurusan Teknik Informatika, Universitas Islam Negeri Sunan Kalijaga, 2014.

[5] Sumiati, Rancang Bangun Sistem Informasi Pengelolaan Surat dan Kearsipan pada Sekretariat Daerah Provinsi NTB. Mataram: Jurusan Teknik Informatika, Universitas Mataram, 2015. 